\title{
Confessions without guilt: public confessions of state violence in Turkey
}

\section{Yeşim Yaprak Yıldız ${ }^{1}$ Patrick Baert ${ }^{2}$}

Published online: 1 July 2020

(C) The Author(s) 2020

\begin{abstract}
Drawing on Austin's speech act theory and on related theories of performativity and positioning, this article analyses the public confessions during the 1990s by three prominent state actors in Turkey about their direct involvement in state crimes against Kurds and left-wing political opponents. All three cases received significant media attention at the time. The aim of the article is not only to shed new light on those specific confessions by the perpetrators within the Turkish context, but also to develop further theoretical insights into the phenomenon of public confessions as such. Whilst confessions of this kind are often welcomed and portrayed as truth-statements that are cathartic and enable society to move forward, this analysis demonstrates that the reality is often more complex as the confessions in question tend to go hand in hand with a disavowal of individual responsibility by the perpetrators involved.
\end{abstract}

Keywords Turkey $\cdot$ Kurds $\cdot$ Public confessions $\cdot$ Performance $\cdot$ Positioning theory $\cdot$ Performativity

Denial and impunity are key features of the Turkish state's approach to mass atrocities perpetrated both in its distant and recent past. Except for several short-lived, partial, and strategic acknowledgments of past state violence and a handful of ineffectual criminal trials and parliamentary inquiries which failed to unearth the full extent of the crimes committed, Turkey has never had a formal process for redressing past state violence. This has also been the case for the crimes committed in the 1990s when the conflict

Patrick Baert

pjnb100@cam.ac.uk

Yeşim Yaprak Yıldız

y.yildiz@gold.ac.uk; yaprakyildiz@gmail.com

1 Sociology Department, Goldsmiths College, New Cross, London SE14 6NW, UK

2 Sociology Department, University of Cambridge, 16 Mill Lane, Cambridge, England CB2 1SB, UK 
between the Turkish army and the Kurdistan Workers' Party (PKK) was at its peak. Yet despite this atmosphere of state denial and impunity, there has never been complete silence on state crimes. On the contrary, discourses on state violence have proliferated, even within the spaces in which power is exercised, as can be seen in parliamentary debates, parliamentary inquiry reports, media accounts, and an increasing number of publications on the Turkish "deep state" which recount the state's extralegal activities. ${ }^{1}$ Most importantly for the aims of this article, beginning in the early 1990s a number of state actors directly involved in crimes targeting Kurdish and left-wing members of the opposition have gone public with their confessions. These revelations have made crucial information available, including forensic evidence on dozens of cases of political killings and forced disappearances, offering rare insight into the operation and structure of state death squads. However, they have led neither to disclosures about the scale of atrocities, nor to conviction of the state actors involved.

Confessional public acknowledgment of state violence by its perpetrators in the face of official state denial and impunity is considered significant, not least because of the nature and extent of the crimes committed. ${ }^{2}$ Human rights groups and victims' associations in Turkey and elsewhere have utilized such confessions to further their demands for truth and justice, despite any lingering doubts, disbelief, cynicism, anger, or revenge they might harbor about the perpetrator or his testimony. ${ }^{3}$ This is often due to the constative aspects of confessions -that is, the mere facts and the forensic evidence they might reveal. However, confessions also produce broader performative effects that might preclude the possibility of truth and justice for past state violence. For although confessions may reveal much-needed information for the family of a victim of state crime, there is a large gap between what such a family demand and what the perpetrators can provide. For the families, the quest for truth and justice goes well beyond the question of what happened to the bodies of their relatives. It often deals with deeper questions: why, by what right, and on whose authority did the act take place? ${ }^{4}$ They demand not simply an account of what happened, but accountability. ${ }^{5}$ In this article we set out to analyze precisely this discrepancy between the discourse of truth in perpetrators' confessions and the truth demanded by the victims.

Our analysis is based on the public confessions of three state actors concerning atrocities committed against Kurds during the 1990s: Ayhan Çarkın, a former police officer within Turkey's Special Operations Police, a security unit at the center of gross human rights violations; Hanefi Avc1, one of the most important state officials in Turkey, who held key positions in the Security Directorate for over 30 years, including as the deputy head of police intelligence; and Abdülkadir Aygan, a former PKK militant, who following his surrender in 1985, worked for the Gendarmerie Intelligence and Counterterror Organization (JITEM), a secret extralegal unit within the gendarmerie. We focus on these three state actors because each was at the centre of infamous cases of political violence and state crimes and received extensive public and media attention. Further, the confessions

\footnotetext{
${ }^{1}$ For a historical analysis of "deep state" see, Göçek, Denial of Violence and Söyler, The Turkish Deep State

2 Jelin, "Investigating What Happened"; Neier, "Rethinking Truth."

${ }^{3}$ Payne, Unsettling Accounts.

${ }^{4}$ Doxtader, "A Question of Confession's Discovery"; Uçarlar and DISA, Hiçbir Şey Yerinde Değil.

${ }^{5}$ Doxtader, "A Question of Confession's Discovery."
} 
of each were widely circulated through broadcast and print media, triggering public debates and criminal investigations.

In what follows, we outline the theoretical framework we employ in our analysis of perpetrators' public confessions of state crimes. We then discuss the rhetorical and performative strategies employed by Çarkın, Avcı, and Aygan in their confessions and the effects their confessions have on the acknowledgment, and admission of guilt and responsibility for state crimes. We finish the article with a discussion of the wider social and political implications of these three public confessions.

\section{Confession, truth, and responsibility}

Lying at the intersection of religion, law, psychoanalysis, and literature, confession is a politically and historically loaded concept. This makes it difficult to define and analyze confessions in an isolated mode. For our analysis, we take confession to be a selfreflexive truth act that is performed in front of an audience and that provides an account of past wrongdoing. While exhibiting certain common features, confessions have taken on varying forms across different domains and historical periods, meaning that context defines both the conceptualization and the reception of confession. Throughout history, confession of wrongdoing has functioned simultaneously as a mechanism of social exclusion and social inclusion: whilst ostensibly pointing the finger at the perpetrators who admit their guilt, it has also made their wrongdoing understandable and forgivable. ${ }^{6}$ Indeed, by singling out an individual or group as guilty of a crime, a perpetrator's confession has often paved the way both for reconciliation between the perpetrator and the victim and for reintegration of the perpetrator into society. ${ }^{7}$ Although there is no historical continuity in confessional practices, confession was practiced as a mechanism of reconciliation with gods in ancient pagan societies (e.g. Lydia and Phrygia ${ }^{8}$ ) and as a mechanism for absolution and forgiveness for one's sins in early Christianity. Confession was also widely used in judicial procedures as a mechanism to establish the truth. While it was considered as the strongest type of evidence in Roman canon law, there are records of the use of confession extracted under torture from the earliest decades of Islam to the Ottoman Empire. ${ }^{9}$ Studies on the genealogy of confession have challenged the presumed naturalness, authenticity and truthfulness of confession and its purported reconciliatory aspect by setting out its close link with power and violence and the varying social and political functions it has taken. ${ }^{10}$ Yet, the therapeutic and linear understanding of confession, often considered as arising from this historical link between confession, truth and reconciliation, has dominated transitional justice processes across the world, reinforcing the belief in the power of "truth" extracted through

\footnotetext{
${ }^{6}$ Hepworth and Turner, Confession.

${ }^{7}$ For how this has been the case in religious and legal uses of confession, see Hepworth and Turner, Confession; and Brooks, "The Future of Confession".

${ }^{8}$ Confession inscriptions found in Lydia and Phrygia from the first to the third centuries indicate the widespread use of the practice. The inscriptions refer to the documents containing confessions of religious offences, crimes and misdemeanours written on stelae and set up in sanctuaries for the aims of seeking forgiveness, dedications and vows and praises for gods (Chaniotis, "Ritual Performances").

${ }^{9}$ See Heyd, Studies; Peters, Crime.

${ }^{10}$ See Foucault, On the Government; Foucault, Wrong-Doing; Taylor, Culture of Confession; Hepworth and Turner, Confession.
} 
confession in healing individuals and societies in the aftermath of periods of conflict and injustice. ${ }^{11}$ Some commentators have argued that this widespread belief in the political potential of public confessions in the last few decades has deeper historical roots within Europe, going back to the centrality of confession in Christianity. Whilst we acknowledge the historical and religious dimensions, there are clearly other dynamics at play as well. These include the early uses of confession in psychoanalysis (known as 'talking cure') which remained dominant in popular culture ${ }^{12}$; and the contemporary fascination with confession in reality TV shows, online confession sites and confessional autobiographies across the world. ${ }^{13}$ Further, the literary form of public confession has exhibited close links with the rise of first-person narratives such as autobiographies and diaries which have never been unique to the West. ${ }^{14}$

The focus of this article is on public confessions by perpetrators outside the contours of officially sanctioned mechanisms, and this shifts the debates on confession's link to truth, responsibility and reconciliation to a different level. ${ }^{15}$ From South Africa to Argentina, ${ }^{16}$ perpetrators of state violence made confessions through media interviews or memoirs. Although the reception of public confessions is heavily influenced by the therapeutic understanding of transitional justice in which truth-telling is supposed to lead to reconciliation, we aim to show that public confessions operate in different modes and contexts. Public confessions of state crimes differ from both confessions of individual crimes and confessions of state crimes extracted by a judicial authority in that they appear at face value to be authentic, spontaneous, and voluntary revelations. Unlike institutionalized confessions structured by specific rules and procedures, public confessions are less rigidly regulated, and shaped by the perpetrator and the editorial and commercial interests of the publishing houses or media organizations where they take place. Their effects are multiplied as confessions are reproduced and reframed by various media, often in a sensationalized way. Furthermore, by revealing contested details about past state crimes, public confessions unsettle their audiences, ${ }^{17}$ often seeming like forms of speaking truth to power. In countries where state crimes have not been accounted for, they gain even more importance as they may unearth evidence of past state crimes.

\footnotetext{
${ }^{11}$ The South African Truth and Reconciliation Commission was the first such restorative justice body to make confession a central component of the mechanism. Setting an emblematic example on the relationship of confession to reconciliation (Moon, Narrating Political Reconciliation, 1; Hamber and Wilson, "Symbolic Closure." the South African example was followed by other countries - Rwanda, Sierra Leone, and Columbia among them - which offered amnesty or sentence reduction in exchange for perpetrators' confessions. The language of redemption through truth-telling and forgiveness have been dominant features of over sixteen truth commissions (Rogers, "Nostalgia," 255-256; Shaw "Memory Frictions.")

12 Taylor, Culture of Confession.

${ }^{13}$ Docherty, Confessions; Brooks, Troubling Confessions.

${ }^{14}$ Challenging the lack of interest in autobiographical literature in Eastern societies in general, scholars such as Lewis and Kafadar give various examples of first-person narratives from the Ottoman Empire including diaries, dream logs, and autobiographies, in addition to other examples in medieval Islamic societies, such as Al Ghazali, Ibni Sina and Nasir-i Husrev (Kafadar, "Self and Others"; Lewis, From Babel). The "fallacy of Western origins' resulted in using structural and rhetorical characteristics of the western autobiographies in 'measuring the level of 'self-consciousness' and 'individual identity' present in other historical periods and other cultures' rather than comparing them and analysing their specific features (Reynolds, Interpreting).

15 Payne, Unsettling Accounts.

16 Ibid.

17 Ibid.
} 
A closer analysis of such confessions and their effects demonstrates that the discourse of truth in perpetrators' public confessions often presents a complex picture of legitimation, justification, glorification, disavowal, or individualization of the state violence. ${ }^{18}$ Rather than functioning solely as a mechanism of social inclusion and reconciliation as has been supposed throughout its history, public confessions might instead serve as a way of redefining the violent acts as noncriminal and thereby validating the perpetrator's point of view. ${ }^{19}$ More often than not, such public confessions inhibit the desired effects of establishing truth, justice, and reconciliation.

As we will argue through reference to the confessions of Çarkın, Avcı and Aygan, public confessions do not always reveal the truth or the mechanisms of responsibility for the crimes committed, but may in fact work to further conceal them. In acknowledging past wrongdoing, public confessions may simultaneously efface guilt and responsibility by means of a range of rhetorical and performative strategies. This is because confession is not solely a constative statement revealing a verifiable truth about a wrongful act; it is also a performative speech act that produces specific effects on the meaning of the confessed act, the confessing subject, the audience, and the relationship between them. ${ }^{20}$

Socio-historical studies of confessions have been heavily influenced by a genealogical perspective, drawing heavily on Foucault's own treatment of confessions in his later work. While Foucault's Discipline and Punish and History of Sexuality focus more on the disciplinary function of confession and situate it within the context of a knowledge/power framework, his lectures at the Collège de France explored the role of the subject and confessional form of truth-telling in maintaining dominant forms of rationality. ${ }^{21} \mathrm{We}$ acknowledge the fruitfulness of the Foucauldian approach to public confessions, but we also wish to point out that his particular focus was on Western Christianity and that there are limitations to applying his insights beyond that specific context. More importantly, both in his early and later studies, Foucault was mainly interested in confessions extracted by an authority or an institution such as religious, judicial and psychiatric institutions, whereas our focus is on public forms of confessions that are seemingly spontaneous and voluntary (and which in some cases seem like speaking truth to power, as they confess state violence). Further, unlike Foucault, we are more interested in the intricate mechanisms of the confessional performance itself and what this performative act manages to achieve. We acknowledge that confessions may well help to maintain dominant power relations and discourses and that a Foucauldian approach would be particularly helpful in analyzing this phenomenon, but we prefer to pay attention to the performative aspects of the perpetrators' confessions and the effects of those performances for how the perpetrators and their past acts are perceived and evaluated.

\footnotetext{
${ }_{18}$ Ibid.; Lazzara, "Writing Complicity"; Lazzara, "Complicity and Responsibility."

${ }^{19}$ Lovitt, "Rhetoric of Murderers."

${ }^{20}$ For performative speech act theory, see Austin, How to Do Things with Words.

${ }^{21}$ Foucault, The Government of Self and Others; Foucault, On the Government of the Living; Foucault, Wrong-Doing, Truth-Telling.
} 
In sum, we will be analyzing the confessions by focusing in particular on their performative aspects: we will be drawing on analogies and metaphors from the stage to make sense of the public interventions in question. Apart from a handful of studies ${ }^{22}$ confessions have not been analysed through the notion of performativity. Although Payne, in her comprehensive analysis of perpetrators' confessions, ${ }^{23}$ emphasises the performativity of confessions referring to Austin in an endnote, she does not extend her analysis to the contemporary discussions around performativity. For Foucault confession in judicial procedures belongs to the order of drama or dramaturgy and he adds that 'dramatic' should not be understood merely as ornamental additions, but as every element in a scene bringing forth the foundation of legitimacy and the meaning of what is taking place. ${ }^{24}$ Yet, he dismisses the idea that confession or avowal is a performative act.

Payne's extensive analysis of confession as performance is fruitful for our study, yet we differ in our conclusions. According to her, confession is an act of performance in which a social actor deliberately takes a public stage in an ensuing political drama. ${ }^{25}$ The theatrical elements of the performance - the actor, the acting, the script, the stage, the various audiences, and the timing-all produce meaning out of confessional performances. $^{26}$ That is, the meaning of the performance is not only produced by its subject in a calculated way but through the interaction of these elements and the wider context. Although Payne acknowledges that confessions do not necessarily “... settle accounts with the past; rather, they unsettle them ..." and that the extent to which they break silence over the past and contribute to reconciliation would depend on the specific context, she also argues that confessions of past state violence lead to a contentious debate which "... enhances democratic practices by provoking political participation, contestation and competition". ${ }^{27}$ We rather focus on the risks and the limitations of the confessional form of truth-telling arising from both the dominant form of confession and the specific context of Turkey.

The legitimacy of confessional performances also often depends on the distribution of power in the society and one's positionality in it. It is worth elaborating on this last point because it is precisely this implied notion of positioning that makes our performative approach distinctive and, in our view, complementary to Payne's performance analysis. To develop this argument, we shall draw on insights from positioning theory, which was initially developed by the philosopher Rom Harré and his associates in the context of the theory of social psychology and discourse analysis. ${ }^{28}$ While Harré and others first introduced positioning theory to further improve our understanding of faceto-face interactions, more recent research has demonstrated the broader applicability of positioning theory well beyond psychological matters of social psychology. ${ }^{29}$

\footnotetext{
$\overline{22}$ Paul de Man, Allegories; Brooks, Troubling Confessions; Derrida, 2002; Terry, "Once Blind Now Seeing"; Doxtader, "A Question of Confession's Discovery". These studies, however, are limited in their focus (the relationship between confession and excuse in Derrida and de Man; performative effects of confession on the confessing subject in Terry; performativity of institutionalised and conventional forms of confession in Brooks).

${ }^{23}$ Payne, Unsettling Accounts.

${ }^{24}$ Foucault, Wrongdoing, Truthtelling, 209-210.

${ }^{25}$ Payne, Unsettling Accounts, 15.

26 Ibid.

27 Ibid. 2-3.

${ }^{28}$ E.g. Harré and van Langenhove, Positioning Theory.

${ }^{29}$ Baert, The Existentialist Moment.
} 
Likewise, our usage of positioning theory rests on the assumption that it can be used for broader sociological purposes.

This brings us to a crucial aspect of a confessional performance: the self-positioning and positioning by the confessing individual. The notion of positioning alludes to the process by which agents, with the help of specific interventions, attribute certain features to themselves and to others. From this angle, confessing subjects use various rhetorical devices, material and symbolic props in order to position themselves and possibly to increase the effectiveness of confession. In other words, they present a narrative that includes implicit or explicit assertions about past crimes, individual and state responsibility and of course remorse. It is important, however, to bear in mind that positioning is invariably a dynamic process in which confessing subjects are never entirely in control of the meanings attributed to their interventions. For instance, the confessing subjects rely on specific media or publishing outlets for the staging of their performance and to get their message across; those channels have their own commercial and political interests which may affect the positioning. More broadly, the positioning of the confessing perpetrators depends on their already established status, their past interventions, the responses or counter-positioning by others in the same field, and the specific historical and socio-political context in which the intervention takes place.

In this article, we employ this specific take on performativity - with the centrality of positioning theory - to confession in order to better understand its immediate and consequential effects on the subjectivity of the perpetrator, the meaning of the confessed act and responsibility associated with it. For the sake of clarity, it is important at this stage to elaborate on the philosophical arguments that underscore this perspective, in particular their relation to ordinary language philosophy. Following John Austin's speech act theory, we treat confessions as not solely constative statements that is, declarations or acknowledgements of wrongdoing - but also as performative speech acts in that they perform an action by saying or in saying something. ${ }^{30}$ From this perspective, what matters about confessions is not so much the truth or falsity of the statements involved, but their force or effect on the speaker and on the audience. ${ }^{31}$

After differentiating between constative and performative speech acts, Austin makes a further distinction between locutionary acts (the utterance of a certain sentence with a particular sense and reference), illocutionary acts (the performance of an action by saying something, such as 'I do' in a marriage ceremony) and perlocutionary acts (the act of eliciting the feelings, thoughts, or actions of the audience, or the speaker or of other people). However, he largely focuses on the illocutionary dimension of a speech act, treating the perlocutionary acts as relatively insignificant. ${ }^{32}$ We follow scholars such as Cavell, Kaufmann and Lorenzini who have unpacked the productive potential of Austin's brief discussion of perlocutionary utterances. It is in this vein that we consider public confession as an example of a perlocutionary speech act.

The effectiveness or success of public confessions depends on different conditions than Austin set out for illocutionary performative utterances. According to Austin, the

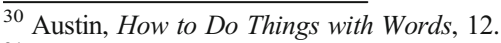

${ }^{31}$ As Brooks shows in a number of examples of confessions in law, people can convincingly confess to a crime that they did not commit due to a strong feeling of guilt because of a different crime or because of an unconscious feeling of guilt. Equally, people might confess to a crime that they did commit, but not in a satisfactory way. See also Brooks, Troubling Confessions; Terry, "Once Blind, Now Seeing".

32 Austin, How to do Things with Words, 101.
} 
felicity of a performative utterance depends on a number of conditions including the existence of an accepted conventional procedure; the appropriateness of particular persons and circumstances for the invocation of particular procedure; the correct and complete execution of the relevant procedure; and the sincerity and intent of the persons executing the procedure. ${ }^{33}$ The felicity of conventional forms of confession such as religious confession, could be analysed by taking into account these conditions. When invoked correctly and according to the established procedures, a religious confession to a priest would result in absolution.

The conditions for the effectiveness of public confessions are different, however. Similar to Cavell's argument about passionate utterances, there are no conventional or established procedures for the confessors, nor for their audience. Besides the fact that the person who is making the public confession must have a direct link to the crime, there are no appropriate or correct procedures for public confessions; they can be made with the help of very different media and deploying very different rhetorical strategies. Whether particular circumstances or procedures are appropriate depends on the social, political and cultural contexts in which the public confessions take place. The effectiveness of those confessions also depends on the specific performance of the speaker, which again will differ according to context. Further, the interlocutor or the audiences might respond in different ways: they might accept the performance and the projected sincerity, they might question it and reject it, or they might use it strategically without necessarily believing in it. This brings an element of unpredictability to public confessions.

For analysing the effectiveness of a public confession, it is worth invoking Austin's notion of the 'total speech situation'. In order to understand the effects of a public confession, particularly the unexpected consequences of public confessions, we should analyse the 'total speech act' in the 'total speech situation'. ${ }^{34}$ That is, the effectiveness of the confession depends on the distribution of epistemic authority in a society, which includes the social class, ethnicity, professional rank of the confessing subject. Further, even though there is no conventional procedure for public confessions to take effect, both the confessing subjects and the audiences draw upon the dominant norms and values and the cultural repertoire of neutralization techniques ${ }^{35}$ in their interaction. By neutralization techniques we refer to a set of culturally specific codes which resonate with the local public and thereby help to explain the acts by the confessors and absolve their responsibility. That is, while a social and political context would give us a strong indication of how a confession will be received by the audiences, by the same token the actual reception provides important insights on the accepted norms and values in that particular social and political context.

Based on this theoretical framework, we will be analysing the confessional performances of Çarkın, Avcı and Aygan. We will explore when, where and how those confessions took place, and we will study the specific rhetorical strategies which they employed. Looking into the perlocutionary effects of confessional speech acts, we seek to understand the effects of confessions on truth, subjectivity and responsibility in

\footnotetext{
${ }^{33}$ Ibid, 14-15.

${ }^{34}$ Austin, How to do things with words, p.147.

${ }^{35}$ Here we refer to Sykes and Matza's theorization of neutralization techniques used by ordinary delinquents to 'neutralize' their crimes; Stanley Cohen reinterpreted this perspective in the context of state crimes (Sykes and Matza, "Techniques of Neutralization"; Cohen, States of Denial).
} 
relation to the past state crimes confessed. This particular angle enables us to see confessions not as simply acknowledgement of the deed committed, but also as interconnected with self-interest. Other commentators have rightly pointed out that at the centre of most confessions is not so much the act confessed, but the confessing subject - that is, his or her psychology, motivations, guilt or innocence. ${ }^{36}$

In our analysis, we will benefit from Stanley Cohen's application of Sykes and Matza's neutralization techniques to state crimes. Indeed, the different forms of denial which Cohen outlınes in his seminal book States of Denial (namely literal, implicatory and interpretive denial) are undoubtedly present in the confessions of Çarkın, Avcı and Aygan. However, we will discuss these forms of denial as part of the confessional speech act, not as external to it. In the literature on perpetrators' accounts, there is a tendency to treat confessions as distinct from excuses, justifications, and denials, confession being an acknowledgement of the act in question. ${ }^{37}$ As we will demonstrate through our three cases, the confessions of the perpetrators constitute a complex entanglement of excuses, justifications, silences, evasion and denial.

From this perspective, confession is not simply a truth-statement, confirming or denying that an event occurred. Confession does much more than making known what was unknown or revealing what was hidden. While appearing as an act of truth-telling, it adjusts and reframes the act in question; and the way in which an act is narrated and rearranged defines the responsibilities that are connected to it. This is by no means to deny that confessions might reveal crucial information about past atrocities, such as the whereabouts of the bodies of the disappeared as in the case of Turkey. Yet, such revelations do not stand alone; they are framed from the positon of the perpetrator within a very specific political and historical context. Furthermore, the victims of atrocities are interested not so much in an account of what happened, but in the responsibility and accountability for what happened. As the analysis of our three cases will demonstrate, confessions often embody a contradiction between the act of purported truth-telling and its implied notion of responsibility on the one hand, and a certain abdication of responsibility on the other. ${ }^{38}$ By employing various rhetorical and performative strategies, perpetrators reconstruct the truth of their acts in such a way as to neutralize the wrongfulness of their acts or to be relieved of responsibility. Confessions thus help perpetrators disavow the meaning of their wrongful acts, breaking the links between themselves, their acts, and the consequences of their acts. Annulling the wrongful act and the subject of the act, confession results in effacing the guilt, responsibility, and accountability attached to them. As we will demonstrate through the case studies below, the act of public confession becomes a simultaneous avowal and disavowal of wrongdoing.

\section{Public confessions of Turkish state actors}

Following the start of the armed conflict with the PKK in 1984, and particularly after the introduction of a state of emergency in the Kurdish provinces in 1987, the Turkish

\footnotetext{
${ }^{36}$ Brooks, Troubling Confessions; Coetzee, "Confessions and Double Thoughts"; Felman, Testimony;

Radstone, "Cultures of Confession / Cultures of Testimony".

${ }^{37}$ Huggins et al., Violence Workers; Scott and Lyman, "Accounts"

${ }^{38}$ Doxtader, "A Question of Confession's Discovery".
} 
state has increasingly resorted to extralegal and illegal methods of warfare, using death squads and paramilitary groups to suppress the Kurdish population. While JITEM has been responsible for a vast majority of atrocities, special forces within the military and the police and far-right paramilitary groups have also committed grave acts of violence against civilians. During this period, Kurdish civilians were subjected to forced disappearances, political killings, arbitrary detentions and prosecutions, widespread torture and forced displacement. As the news of the atrocities spread through the testimonies of victims and eyewitnesses, reports by local and international human rights organizations, parliamentary debates, and the media, the state has engaged in various forms of denial, ranging from outright denial of the existence of any violation, to partial acknowledgment and rationalization in the name of national security and counterterrorism. This complex picture of denial and acknowledgment has been further confounded by the convoluted picture of truth emerging from perpetrators' confessions.

Remorseful confessional performances are rare in Turkey, the dominant form being proud, patriotic, and heroic. Confessions made with expressed feelings of remorse, however, are also marked with complex layers of feeling that also include anger, pride, guilt, resentment, revenge, and betrayal. Such are the confessional narratives of Çarkın, Avc1, and Aygan.

\section{Ayhan Çarkın}

Ayhan Çarkın, a former Special Operations police officer, took part in frequent armed operations against left-wing militants and Kurdish political activists and businessmen who were allegedly supporting the PKK. He first came to public prominence in 1996 with the Susurluk scandal following a traffic accident in the northwestern town of Susurluk. The accident exposed the depth of the relations between the Turkish state, the police, and the mafia, as one of the vehicles involved was carrying a member of parliament who directed the largest paramilitary village guard clan, the deputy chief of the Istanbul Police Department, and a former leader of the ultranationalist militant group, the Grey Wolves (Ülkü Ocaklart), then listed on Interpol's Red Notice owing to his involvement in pre-1980 massacres of leftwing activists. ${ }^{39}$ The three were on their way back from a visit to the interior minister. Çarkın, who had worked closely with the state officials involved in the scandal, found himself at the centre of the scandal and spent 2 years in prison.

After he was released from prison in 2002, Çarkın made frequent media appearances during which he confessed to having killed people during the armed operations he took part in, while emphasizing that these actions, which he described not as murders but instances of national self-defense, had been "authorized by the state." acts in the name of counterterrorism, he claimed that certain factions of the state had deceived Special Operations policemen in order to personally benefit from the war. ${ }^{41}$ Following these ambivalent performances alternating between glorification and denial of state violence, Çarkın reappeared in 2011, with a remorseful performance. Attending

\footnotetext{
39 Sabuktay, Devletin Yasal.

${ }^{40}$ See Arman, "Devlet."

41 “Ayhan Çarkın: 1000 kişiyi öldürdüm (I killed 1000 people)”, Milliyet, October 21, 2008. Accessed September 10, 2018 http://www.milliyet.com.tr/ayhan-carkin\%2D\%2D1000-kisiyi-oldurdum-gundem1005903/
} 
the Newroz ${ }^{42}$ celebrations in Taksim Square, Istanbul, he was noticed by a journalist and later gave him an interview acknowledging state-sanctioned atrocities against Kurds and left-wing activists. "I was part of the first Special Operations team of 320 people sent to the southeast in 1986. I stayed in the region until 1990. We were all of us covered with blood. Terrible things were done to those people. In one village, we saw that an officer was beating a man naked in the middle of the village in front of children. What kind of mentality is this to beat a Kurd naked claiming that he supports the PKK?..This is not what counterterrorism is; it is a betrayal. I saw that warplanes were used against these people; artillery, tanks, mines were used. This fire will burn us all. We made them eat shit. We pulled out their nails, we banned their language. We did it...We need to apologize to the Kurds. Now there are mass graves everywhere... These mass graves are this country's disgrace." When asked why he has chosen to confess at this juncture, he says, "I went to Nevruz with my wife, my children, and my friends. I went there as a Turk and as a murderer. I went to the platform and asked them to allow me to speak. What makes me speak now is my conscience. I want to free myself from the darkness inside me. I am calling on my colleagues. You should also come out and recount what you know. We have to speak out."43

\section{Hanefi Avcı}

During his 17-year service in the counterterrorism unit of Mersin Security Directorate, Hanefi Avc1 is held responsible for numerous acts of torture against left-wing activists and members of armed left-wing organizations. ${ }^{44}$ He worked in Diyarbakır between 1984 and 1992, a period when he had close links with JITEM commanders and hitmen involved in forced disappearances and political killings. Avcı came to public prominence in 1996 as the then Deputy Head of Intelligence at the General Directorate of Security during his revelations to the Parliamentary Inquiry Commission on the Susurluk scandal regarding the illegal and extralegal activities of state officials during the war against the PKK. ${ }^{45}$ He appeared before the Parliamentary Inquiry Commission on the assassination of Cumhuriyet journalist Uğur Mumcu in 1993, sent a letter in 1997 to the Chief of the General Staff on the relations between certain military officers and the mafia, ${ }^{46}$ and made further revelations on JITEM during court testimonies and television appearances. $^{47}$

Positioning himself as an honest and courageous state official willing to take personal risks in order to reveal dirty relations within the state, in 2010 he published a book with the

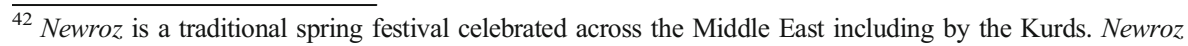
celebrations are highly politicized in Turkey, often brutally put down by security forces, as they have been occasions for Kurds to demand their social, cultural, and political rights.

43 "Çarkın'dan tarihi çark: Ben iki Abdullah sevdim" (Historic turn from Çarkın: I loved two Abdullahs), Radikal, March 22, 2011, accessed September 10, 2018, http://www.radikal.com.tr/turkiye/carkindan-tarihicark-ben-iki-abdullah-sevdim-1043705/.

${ }^{44}$ Türker, Yıldırım. "Hanefi Avcı'nın suçu ne?” Radikal, October 4, 2010; Mavioğlu, Ertuğrul. "Hanefi Aveı Ne Zaman Devrimci Oldu?", Radikal, 30 September 2010.

45 "Susurluk Sonrası (Susurluk Aftermath)," Bianet, November 1, 2001. Accessed September 10, 2018. http://bianet.org/bianet/siyaset/5777-susurluk-sonrasi.

46 "Hanefi Avcı ordunun isteğiyle görevden alınıyor (Hanefi Avc1 is being removed from his post at the army's request)," Cumhuriyet, April 10, 1997.

47 “Avcı: Yeșil MíT tarafindan kullanıldı (Avcı: Yeșil was used by Miт),” Cumhuriyet, April 16, 1998.
} 
unusual title of Haliç'te Yaşayan Simonlar (Simons Who Live in Haliç), ${ }^{48}$ in which Avc1 uses the codename of a PKK militant he knows to refer to those who do wrong in the name of a higher ideology. The book indexed revelations and confessions on unlawful methods of gathering intelligence or silencing political opponents: torture and ill treatment; house searches without a search warrant; detention without arrest; illegal phone taps; pressuring of the judiciary and JiTEM's activities. ${ }^{49}$ His book was advertised with the following statement: "Hanefi Avc1, the legendary policeman who proved himself a true lawman with his brave position during the Susurluk period continues to tell the truth. He exposes [here] the secrets behind recent events solely so as to fulfill his moral responsibility regardless of who may be harmed." ${ }^{50}$ Avc1's book has been widely circulated and was the bestseller in 2010 selling over 600.000 copies in just 2 weeks. ${ }^{51}$

In a bid to explain his decision to write his memoir, Avc1 oscillated between remorse and resentment. On the one hand, he invoked a higher purpose and morality: "I was involved in numerous incidents I cannot even remember. I did many things. But I demolished some of these things, and I believe that they all need to be demolished. I will try to demolish some more with this book. I grew up believing in right-wing ideology and moral values about homeland, state. and nation...But in time, certain events I witnessed made me question these transcendent values." Then, he explained how he began questioning his own ideology and that of the "Simons" involved in wrongful acts in the name of a higher ideology: "I promised myself... I would stand against anyone who does wrong, including those on my own side, my own friends. No matter how powerful they were and whatever the costs, I would stand against them."52 On the other hand he recounted his own self-interest: "I then suddenly found myself being downgraded from the position of the police, the state's security force; that is, from the position of the hunter to that of an undesirable target - the hunted., ${ }^{, 53}$

\section{Abdülkadir Aygan}

Like other former PKK members who collaborate with the state and confess to the military following their surrender or capture, former PKK member turned JITEM officer Abdülkadir Aygan ${ }^{54}$ is referred to as a "PKK repentant." Aygan is one of the most well-known of the PKK repentants in that he divulged detailed information on the structure and functioning of JITEM and gave specific information on some 30 cases of forced disappearances and political killings in his confessions starting from

\footnotetext{
${ }^{48}$ Avc1, Haliç'te.

${ }^{49}$ Avc1, Haliç'te, 87. The book is composed of two parts, the second dedicated to the infiltration of Fethullah Gülen supporters in the military and the security units. The section on state crimes also includes his revelations on big scale corruption cases involving state officials.

${ }^{50}$ See the online bookseller İdefix's page for Avc1's book, http://www.idefix.com/Kitap/Halicte-YasayanSimonlar/Hanefi-Avci/Arastirma-Tarih/Politika-Arastirma/Turkiye-Politika-/urunno=0000000341498.

${ }^{51}$ According to a list released by Forbes magazine, Avc1 was among the three highest-paid Turkish authors in 2010. See "Hanefi Avcı en çok kazanan yazar!" Akşam, May 3, 2011, accessed September 10, 2018, http://www.aksam.com.tr/amp/kultur-sanat/hanefi-avci-en-cok-kazanan-yazar\%2D\%2D37474h/haber-37474. 52 Akçura, Teskilatin, 91.

53 Avc1, Haliç'te, 4.

${ }^{54}$ For an analysis of Aygan's confessions in comparison with the heroic confessions of higher-ranking JITEM officers, see Yıldız, Y. Y. (2019), "Confession as Disavowal: JiTEM officers confessing atrocities against Kurds during the 1990s", in: Kurds in Turkey: Ethnographies of heterogeneous experiences. eds. Adnan Çelik and Lucie Drechselova. Lanham, MD: Lexington Books.
} 
2004. ${ }^{55}$ PKK repentants were used by JiTEM and other special security units in operational and psychological intelligence-gathering, in operations involving the abduction, torture, and killing of Kurds, and in paramilitary death squads. ${ }^{56}$

Having worked for JITEM in Kurdish provinces for 14 years, Aygan was appointed to a passive post in the western province of Burdur in 1999. Following his prosecution for another torture case there along with other military officers, he resigned from JITEM, expressing his feeling that he had been used and sidelined. In March 2004, a Kurdish daily Ülkede Özgür Gündem (Free Agenda) tracked Aygan down and interviewed him in exchange for helping him to flee to Europe. ${ }^{57}$ His initial confessions in 2004, which included detailed information on dozens of forced disappearances, received little media attention until the body of one of the disappeared was found at the location Aygan had described.

Aygan reappeared in the mainstream media in 2007 following the Ergenekon trial, dubbed as one of the 'deep-state' trials in Turkey. The indictment, which included some of the defendants in the Susurluk and JITEM trials (including Brigadier General Veli Küçük and Colonel Arif Doğan) and some 200 retired and active military officials, state officials, security officers, and ultranationalist militants, made an explicit link between the Ergenekon organization and the "deep state. ${ }^{58}$ Since then, publications on Aygan's confessions have increased: in addition to a book written by the journalists who interviewed Aygan in 2004, ${ }^{59}$ several volumes have been published about him and JiTEM. ${ }^{60}$ Aygan also appeared at this time in a number of TV shows in which he enacted a remorseful performance, strengthened with his regretful and helpless look and lapses of silence. In his interviews, Aygan often depicted a detailed trajectory of his life in a bid to explain why he joined the PKK and JITEM. He often referred to his conscience, being used by the military and their betrayal of him simultaneously when explaining the reasons for his confessions. Positioning himself as a truth-teller, he said "I strived to fulfil my human duty by divulging a dirty war organisation JiTEM.... By revealing unsolved killings committed by JITEM, I tried to prevent other possible killings in the future. I wanted for those who lost their relatives to have a grave where they can cry. I wanted to ease my conscience, by sharing the secrets that preyed on my mind and tormented me for years." ${ }^{\text {61 }}$ Such statements were often followed by Aygan's claims to have been used and discarded by JITEM. ${ }^{62}$

\footnotetext{
55 "Cinayetlerin Merkez Üssü: Saraykapı", Bianet (source: ülkede özgür gündem), March 10, 2004. Accessed on 22 October 2018. https://m.bianet.org/bianet/insan-haklari/30807-cinayetlerin-merkez-ussu-saraykapi.

${ }^{56}$ Kılıç, JITEM.

57 "Cinayetlerin Merkez Üssü: Saraykapı", Bianet.

58 “'Deep state' trial polarises Turkey”, BBC News, October 23, 2008. Accessed on 23 October 2018 http://news.bbc.co.uk/1/hi/world/europe/7684578.stm. Also see Ertür, "The conspiracy archive: Turkey's deep state on trial".

${ }^{59}$ Şahan and Balık, İtirafçı.

${ }^{60}$ Çiçek, Itirafç̧ı; Çiçek, Gerçek; Kılıç, JITEM.

${ }^{61}$ Çiçek, Gerçek, 30.

${ }^{62}$ See Çiçek, Gerçek, 176-177.
} 


\section{Rhetorical strategies in confessional performances}

The confessions of Çarkın, Avcı and Aygan took place at critical political junctures in Turkey, following internal conflicts between different factions within the state, mainly over the economic and symbolic gains during the conflict. ${ }^{63}$ This manifested itself through well-publicized scandals, political trials and parliamentary inquiries into state violence. This specific context enabled the emergence of these confessions and it also shaped the confessional narratives and the way in which they were received by the public. The perlocutionary effects of public confessions are complex. Whilst it remains difficult to fathom the precise motivations or intentions of the confessing subjects, an in-depth analysis of their performances and of the rhetorical strategies which they employed can give us insights into how those confessions tied in with notions of responsibility and with societal understanding of state violence in that particular context.

Emanating from dissimilar rhetorical and performative strategies, denial of responsibility runs as a common motif through the confessional narratives of Çarkın, Avc1, and Aygan. The most obvious common strategy employed is the denial of agency, intent, and choice through appeals to the chain of command, professionalism, necessity, self-defense, or higher loyalties to family and homeland. ${ }^{64}$ In order to deflect responsibility from themselves, all three place the blame elsewhere-on individuals, organizations, systems, or abstract allegiances.

In describing the killings that he carried out, Çarkın impugns both his superiors and his patriotism, and professionalism. "Extrajudicial killings were committed in the operations I was involved in"65 he acknowledges, immediately launching into an account of how they were cheated by their superiors in the name of national security and counterterrorism. "Would the state lie to its citizens, to its police officers? Would the state use and deceive its own civil servants?"66 Arguing that the crimes committed were authorized by state officials, he invokes those higher up. "If I made a mistake, I am ready to pay for it. But the murderer is the one who gave the order." Çarkın's readiness to pay the price of his crimes comes with a condition - the punishment of his superiors. "The orders were carried out, and those who gave the orders stepped aside... Do you really believe that blood can be spilled without the state's knowledge?"

The form of denial in the case of Avc1 differs from that of Çarkın owing to Avcı's higher rank and status. Rather than blame his superiors or the state, Avc1 denies his own agency by blaming his ideological indoctrination, the institutional culture of state security structures, and "the system". Although Avc1 does not shrink from acknowledging the beatings in detention, he presents a sterilized version of the interrogations in which he participated. Distancing himself from the narrative and without commenting on the grave consequences of torture on his victims, he explains the prevalence of torture as a systemic issue, which he attributes to ineffective intelligence-gathering methods, inadequate training, and the institutional culture within Turkish security apparatuses. In response to a question by Ruşen Çakır, a journalist who had also been

\footnotetext{
${ }^{63}$ For a discussion of 'solidarity networks' amongst the different factions within the state during the 1990s, see Bozarslan, 'Network-building'.

${ }^{64}$ Cohen, States of Denial; Sykes and Matza, "Techniques." Also see, Arendt, Eichmann.

${ }^{65}$ Cüneyt Özdemir, Interview with Ayhan Çarkın, 5N1K, CNN Türk.

${ }^{66} \mathrm{Ibid}$.
} 
tortured, about why Avc1 had not discussed the use of torture in his book despite its prevalent use at the time, Avcr replies,

I cannot put everything in this book. I might write about it later. It is easy to accuse individuals on that topic, but torture was the only interrogation method until 1999...You cannot accuse me, or this or that person. As soon as Turkey began the EU membership negotiation process in 1999, interrogation methods were developed - we developed new crime investigation and evidence-gathering methods. $^{67}$

In Avc1's narrative, torture becomes an open secret of the time: "Everyone, from police chiefs to prime ministers, knew about this situation, but they all acted as though it does not exist." 68

Avc1's confessional account is couched in bureaucratic and technical minutiae concerning the improved intelligence system that he established, the lack of which he cites as the reason for the earlier prevalence of torture. In this way, he transforms himself from torturer into savior. Defying the possibility of prosecution for torture, he declares that "the heaviest judgment is the one enacted in your own conscience." 69 The logical sequences carefully and methodically set out in his book linking the wrongdoings of the state to the deficiencies of the system relinquish him of any responsibility. He constructs the system as the main perpetrator, with individuals as cogs in the machine; this is a rhetorical device often used by perpetrators, as pointed out by commentators on the Nuremberg trials and the Eichmann trial. Avc1's references to widespread complicity in state institutions and obedience to authority turn his confession into an accusation of collective guilt. His positioning as an outsider is most visible when he expresses his shock at Turkish citizens' silence and complicity in the face of widespread killings. "Turkey is a strange country. Serious crimes are committed in a pervasive manner and are known to everyone including state authorities. But everyone acts as if they don't know a thing."

Aygan positions himself in his narrative as having been both a passive aide and a witness. He accomplishes this by blaming his past, the prevailing circumstances, and the chain of command and by positioning himself as a cog in the machine. Describing his role as a 'civil servant', he says 'I was a civil servant in Diyarbakur. I was not a member of Special Team or an interrogator. I have official documents proving that. I witnessed the unofficial and illegal acts of a state unit where I worked by chance. In that sense I aided them."70

Aygan's initial confessions to the Kurdish newspaper Ülkede Özgür Gündem focus on JITEM's atrocities and Aygan's role in them. ${ }^{71}$ In his later interviews with mainstream Turkish media outlets, however, Aygan emphasizes the chain of command and his submissive, even passive role without assuming personal responsibility for the acts he committed. Regarding the JITEM trial in which he is being prosecuted, he says that "They think that they can cover up the case by prosecuting a few civil servants, I mean,

\footnotetext{
${ }^{67}$ Çakır, "Yazı ișleri."

${ }^{68}$ Ismail Saymaz, "Hanefi Avcr: 28 Subat'ta bile insanlar bu. kadar susturulmadi”, Radikal, 1 July 2014.

${ }^{69}$ Ibid.

${ }^{70}$ Çiçek, Gercek, 271.

${ }^{71}$ Şahan and Balık, İtirafçı, 71.
} 
repentants and one or two sergeants. These people did not commit these acts on their own. No civil servant or subordinate would do something like that without instruction from their superiors." 72 And he adds "Even if I worked in JiTEM or not, these killings were going to be committed". 73

Situating himself as both the target of the PKK due to his betrayal and the target of the state due to his political past and his vulnerable position as a repentant, Aygan argued that it was impossible for him not to do what he was ordered in JiTEM to do. Because the majority of PKK repentants were recruited as civil servants into the gendarmerie after having been provided with a new identity, Aygan's emphasis on his submissive role and his lack of choices works to relieve him of personal responsibility. He often downplays and sanitizes the acts of violence he committed or participated in. Through his performance as a remorseful and transformed individual, Aygan's confessing subject masquerades as the unwilling object of the wrongdoing.

Splitting the self - that is, creating a discontinuity between the self who committed the crime and the self who confesses to it-is another common strategy running through the confessions of Çarkın, Avcı, and Aygan. This ties in with a temporal discontinuity - a clear distinction between the past and the present. The life of the confessing subject thereby falls into a before and an after, "the before being 'an abyss of error,' the after a time of 'everything reversed.",74 Acknowledging his presence before and during the act, the confessing subject says, "I was there, I did it," but then adds, "I am not that person anymore."

Çarkın tries to turn his negative public image around by presenting himself as a conscientious, morally upright person ready to pay for what he has done. While admitting to wrongdoing, his performance is that of someone who has reformed and whose aim is to help uncover the truth. The timing of his remorseful confessions after attending Kurdish Newroz celebrations supports his self-positioning as a reformed individual who expresses solidarity with the Kurds. His occasional religious references, particularly concerning the examination of one's conscience before God in the afterworld, lends similar evidence of his transformation.

In his confessional performance, Avc1 derives his authority both from the past self which he denounces, and the new self which he constructs through the act of confession. Through references to his past professional experiences and former self, he claims to know very well the mentality of the nationalist far-right as he used to think that "all opponents of the regime, the state, the military, and the police as malevolent foreign agents and traitors" and "all radical opposition was to be eliminated". ${ }^{75} \mathrm{He}$ then describes his self-transformation confessing that "the values I sincerely believed in and for which I worked day and night without expecting any material benefit were not the answer, that they were in fact the source of all our problems...I want to clean out the wrongdoing and find the right path". 76

The claim of self-transformation, which materializes during the act of confession, serves to remove claims of wrongdoing for the "reformed" subject. With this discontinuity between the present confessing subject and the former confessed self, notions of

\footnotetext{
72 Düzel, "JíTEM itirafçısı."

${ }^{73}$ Çiçek, Gercek, 30.

74 Coetzee, "Confession and Double Thoughts", 201.

75 Akçura, Teşkilatın Adamları, 52.

76 Ibid., 53.
} 
responsibility and accountability for the wrongdoing are being eroded. Not only is the "new" self being portrayed as genuinely different from its previous manifestation and therefore not responsible from past actions, but the "old" self is also portrayed as one that was duped and manipulated. Given its deluded misguided state, it could not be held responsible, even at the time, for the atrocities committed.

Unlike Avcı and Çarkın, whose confessional performance functions as an act of conversion, Aygan's subject position in his confessional narrative is more volatile. While he denies agency and autonomy regarding his involvement in both the PKK and JITEM, he lays claim to a steady subjectivity and absolute morality, arguing that he never got used to what he was forced to do. He asserts this continuity of self across his repeated switching of sides in a 2012 interview. Referencing his good intentions during his PKK and JITEM years, he attempts to offset his crimes by highlighting elements better aligned with normative behavior.

I set off to defend the rights of the oppressed when I joined the PKK. I discovered that we had been deceived, that the organization did not serve the needs of the oppressed but those of the oppressors. And then I split. When I took the position in JITEM, I thought that I would be able to fight against those who encroach upon the rights of the oppressed. But in time I understood that there is no difference between the PKK and JiTEM. Although seeming opposites, they were serving the same cause...I do not expect any personal benefit from my revelations. I want my people who follow the PKK to see the truth. I want the state to review its wrongful policies, past and present. $^{77}$

Aygan and Çarkın frequently refer to the difficulties of their jobs, depicting their lives as shattered and themselves as financially and psychologically depressed. Aygan enumerates the consequences of his depression including alcoholism ${ }^{78}$ and the disintegration of his family life. "My work at JiTEM damaged my personality. You can govern your will only for a time. After a certain point, you weaken and end up being defeated by your environment and the circumstances." ${ }^{\prime \prime 0}$ Çarkın, on the other hand, says "This is not just about Kurds or Turks. My friends were also killed. There are many people who faced injustices and were killed". ${ }^{81}$ Claiming that many others like him continue to suffer and face injustice because of their confessions, he normalizes the crimes he and others have committed. "None of us are innocent. Telling the truth is always a net gain. We may make mistakes, we may commit wrongs - this is in the human genome." Self-victimization is a common theme in the narratives of perpetrators who engage in remorseful performances. ${ }^{82}$ By this logic, they become the victims of circumstances - their violent surroundings, their upbringing, their working conditions, or their professional commitment. ${ }^{83}$ Çarkın positions himself as a victim of patriotism, nationalism, professionalism, his superiors, and the state

\footnotetext{
77 Yaraș, “Abdülkadir Aygan,” 106.

78 Düzel, "JiTEM."

${ }^{79}$ Çiçek, Gerçek, 186; Şahan and Balık, İtirafçı, 70.

${ }^{80}$ Çiçek, Gerçek, 186.

${ }^{81}$ See Cüneyt Özdemir's interview with Ayhan Çarkın at 5N1K, CNN Türk, 22 March 2011, retrieved from https://www.youtube.com/watch?v=WYKdLsGp2aw.

${ }^{82}$ Payne, Unsettling Accounts; Lazzara, Complicity; Foster et al., Theatres.

${ }^{83}$ Foster et al., Theatres, 48; Payne, Unsettling Accounts, 235.
} 
as a whole; Avc1 projects himself as a victim of the system, the corrupt institutional culture and ideology; Aygan presents himself as the victim of the PKK, the state, his traumatic childhood, and the war. Self-victimization is thus a form of evasion that serves to deflect attention from the victim to the perpetrator.

Through denial of agency, recitation of excuses, and presentation of themselves as victims, confessing perpetrators reframe and readjust their subjectivity so as to efface their responsibility. State actors who engage in remorseful performances reframe the crime in question by minimizing both it and its consequences. While Çarkın, Avcı, and Aygan all confess to having committed the heinous acts of extrajudicial killings and torture, they couch their discussion of these crimes in euphemisms, language codes, and ambiguous phrasing. This woolly use of language and syntax puts a haze of mental confusion over our apprehension of the acts and the actors, at once diminishing their gravity and distancing them from their perpetrators. Instances of torture and other heinous acts are rendered in passive sentences - "he was killed" - or are attributed to collective pronouns - "they killed him". Aygan often refers to torture as "interrogation" and narrates the cases of torture and killings he was involved in using a sterilized language. Although Avcı admits that torture was widespread and systematic, his personal accounts of such cases is limited to "beatings in detention." Instead, he frames the armed operations he masterminded and the extrajudicial killing of left-wing militants, as successful police operations against dangerous radical armed groups that threatened national security.

In their confessions, Çarkın, Aygan, and Avcı blame the Turkish deep state. Because a wider state mechanism is in fact at work in cases of political violence in Turkey, confessions that reference the deep state can successfully establish a sympathetic relationship with the audience. But there is a fine line here. Given that references to the system are often elusive and ambiguous, the intricate relationships between state institutions and illegal organizations remains fundamentally unknowable for the audience. "The system" then functions in these narratives as an empty signifier with no identifiable referent that can ultimately relieve these remorseful confessors of their individual responsibilities.

These confessions are not simply constative statements about the acts that Çarkın, Avc1 and Aygan committed, but rather detailed explanations entangled up with excuses, justifications, evasions and denial. Dominated by the rhetorical and performative strategies discussed above, they reconstruct their subject position and actions in such a way as to diminish the responsibility of the confessing subject and to lessen the severity of the confessed act. During the act of confession, accountability tends to be diminished because confession enacts a clear break between the past and the present. That is, the confessing subject operates in the present while the subject answerable for the atrocity are situated in a distant past. Portraying themselves as having undergone a massive transformation, the confessing subjects can no longer be the subject of wrongdoing.

This transformation is further supported through the confessional narrative in which the subject explains why he did what he did. The confession constructs the misdeed as an inevitable consequence of the personal or professional trajectory of the perpetrator. ${ }^{84}$ The actions and motives that led to the misdeed are sometimes generalized and normalized as if they part of the human condition. The upshot of this is that the

${ }^{84}$ Tell, Dave. "The "Shocking Story" of Emmett Till and the Politics of Public Confession". Quarterly Journal of Speech. 942 (2008): 156-178. 
confessing subject is no longer confessing anything; the misdeed being discussed is now an act that anyone would commit given the circumstances. Çarkın's frequent references to the chain of command, Avc1's analysis of widespread corruption and complicity, and Aygan's stories of being caught between a rock and a hard place serve to construct each confessor as little more than a $\operatorname{cog}$ in a vast machine, a situation where it seems suddenly reasonable to the listener to think that anyone in their position might act in such a way. Such narratives function not only to absolve the confessor of guilt; they also invite the audience to share in the confessor's perspective on their guilt. In that sense, they present their wrongdoing in a depoliticized way. ${ }^{85}$

The banality of our three confessors' appeals to their ideological indoctrination, professionalism, patriotism, loyalty, and submission to a chain of command work toward concealing the personal interests that motivated their acts and distributing their guilt and responsibility among others. ${ }^{86}$ Indeed, what is striking is their indifference to the consequences of their acts and to their victims, their resort to threadbare clichés and their abandonment of individual responsibility for the atrocities in which they were implicated. Their confessional performances, including the timing of their confessions and the rhetorical strategies which they employed, demonstrate that effacement of their guilt and responsibility was one of the main effects of their confessions. However, their confessions have also had wider political consequences. Their rhetoric and frequent media appearances that confess to political violence without any real consequences have led to a banalization of the crimes committed against Kurds. ${ }^{87}$ Widespread impunity for state crimes, a militarized public sphere, the nationalist and militarized language of the media, and the constant sacralization of war have created a distinct atmosphere in Turkey in which acts of violence have become normalized and the moral fabric of the society eroded. ${ }^{88}$ While such an atmosphere has prepared the ground for the emergence of a culture of confession to state crimes in Turkey, those confessions have further reinforced that atmosphere by normalizing guilt and wrongdoing.

\section{Concluding remarks}

The conventional effects of confessions are considered to be establishing truth and apportioning responsibility. Public confessions, however, are very different, especially if we consider their long-term consequences. Through an analysis of perlocutionary effects of public confessions with a focus on the confessional performance, positioning of the confessing subject and rhetorical strategies, we have argued that public confessions result

\footnotetext{
${ }^{85}$ Ibid., 166.

${ }^{86}$ Gürbilek, Sessizin Payl, 34.

${ }^{87}$ Here it must be noted that while there has not been any real judicial threat for any of these state actors, their treatment indeed differed owing to their rank and ethnicity. In contrast to Avc1, a higher-ranking status official, Çarkın, a lower-ranking police officer and Aygan, a Kurdish defector in JiTEM, initially faced imprisonment and prosecution in relation to the acts they confessed, albeit both cases eventually ended with acquittal and in that sense presented a continuity with the way such cases of political violence are dealt by the Turkish judiciary. Likewise, in comparison to Avc1, there was more opposition to Çarkın and Aygan's selfpresentation as truth-tellers. Aygan was particularly targeted.

${ }^{88}$ For militarization of the public sphere see Navaro-Yashin, Faces of the State and Altınay, Ayșe Gül, The Myth of the Military-Nation. For normalization of violence, see Göçek, Denial of Violence and Zerubavel, Elephant.
} 
in effects which preclude the presumed effects of confessional speech acts. Public confessions of Çarkın, Avc1 and Aygan amount to disavowal of their guilt and responsibility.

There are both structural and contextual reasons for the failure of public confessions of perpetrators to establish truth and apportion. The confessions appeared first and foremost like self-serving acts, presenting more acceptable self-positioning to the public. Brooks is right when he argues that the events referred to in a confession are not necessarily the confession's meaning. In his own words, the “... need to confess speaks of guilt, certainly, but it does not necessarily speak the guilt." 89 The focus is on the perpetrator at the moment of his speech act of confession, rather than the perpetrator at the moment of wrongdoing committed. It is not about what happened or who it happened to, but what the perpetrator thinks and feels about what happened. Sensationalist media representations further contribute to this shift. In each of the three cases analyzed here, the media paid more attention to the perpetrators than to their acts or victims. Each perpetrator appeared on prime-time news and television programs with large audiences. The books which they authored or those written about them sold thousands of copies. Just like the media spectacle is focused on the confessing subject and his performance of confession, the response of the perpetrator to the act he committed and its social and political consequences remains limited at the level of his speech act. The idea is that the speech act sheds light on the darkness of the past, reveals the truth, contributes to justice and reconciliation, and hence redeems the perpetrator. In this way, the act of confession reduces the historicity of the act to the single act of confession and proposes the speech act of confession as the adequate response to the acts committed. It is difficult to see how these self-interested aspects of confession, whether intended or unwitting, would be compatible with any transformative potential it may possess. Indeed, media interest in Çarkın, Avc1, and Aygan did not translate into a significant interest in the sufferings of the Kurds or in the wider political and historical aspects of state violence.

The substitution of legal guilt with moral guilt further limits the possibility of political and social transformation. ${ }^{90}$ Despite their acknowledgment of the acts they committed, Çarkın, Avcı, and Aygan each withstood the potential legal consequences of their confessions. Agamben rightly argues that it has become common for public confession of moral wrongdoing to supplant admission to legal guilt: "The contrite assumption of moral responsibilities is invoked at every occasion as an exemption from the responsibilities demanded by law." 91 As we see in the emotions expressed by the low-ranking state actors Çarkın and Aygan, they first substitute their legal guilt with moral culpability through the enactment of regret and remorse, only to efface personal responsibility thereafter, blaming the state or people higher up. The substitutions taking place between the confessing subject and the confessed act and legal guilt and moral guilt as discussed above show that confession is not necessarily about the wrongdoing confessed or the victims, but the perpetrators themselves.

It is important to remember that in the Turkish context, those confessions refer to state crimes that have not been recognized officially, and it is precisely this atmosphere of impunity which has enabled such confessions. Providing a stage for perpetrators to give accounts of themselves and their acts without any real judicial consequences is both a legal and ethical undertaking. What circulates through the sensationalistic media

\footnotetext{
${ }^{89}$ Brooks, "Future of Confession", 71.

90 Yildız, "Confession as Disavowal".

${ }^{91}$ Agamben, Remnants of Auschwitz, 24.
} 
is yet another form of impunity for perpetrators who are allowed to speak freely whilst the victims and their relatives have no voice. Besides, the confessional narratives further reinforce the normalization of state violence against Kurds and the leftist opposition and the widespread indifference to their suffering. Denial and indifference following the revelations of such collective violence corrupt and undermine public ethics and the justice system in Turkey. ${ }^{92}$ In this particular case, the acts confessed were not considered significant enough to deserve prosecution and condemnation, nor was the involvement of these state actors considered morally abhorrent enough for them to be socially excluded. In this context, when, where and how perpetrators speak and the platforms they are given are crucial legal and ethical questions.

Whether or not perpetrators' confessions transform themselves or their audiences is a most important political question. Judith Butler argues that the act of "giving an account of oneself" necessarily involves others in a responsive and responsible relation with us, and those who give the account must be willing "to become undone in relation to others." 94 The perpetrators of Turkish state crimes giving confessional accounts are hardly willing "to become undone". As Michael Lazzara argues in relation to the confessional accounts of the post-Pinochet-era Chile, "Where no expiation occurs, where no willingness to accept punishment or consequences exists, an ethical standard cannot be met." 95 The confessions examined here are not responsible and responsive interactions with others that transform the understandings of state violence in Turkey nor do they lead to the possibility of ending and redressing it. ${ }^{96}$ By controlling their self-positioning and rationalizing and normalizing their actions, perpetrators foreclose the possibility of self- or societal transformation.

As we have defined confession as a performative and relational act where the audiences' reception and other interventions continually contribute to its positioning, we fully recognize the possibility that confession of state crimes can yield unintended and unexpected results, some of which may be more in line with the interests of the victims and their families. Further, the framing of perpetrators' confessions through the lens of the victims, as the opposition media do, ${ }^{97}$ may indeed shift the meaning of the confessional performances. ${ }^{98}$ However, the confessions of state crimes reported by the mainstream media takes place in an atmosphere of government censorship and

\footnotetext{
92 Göçek, Denial of Violence.

${ }^{93}$ Butler, Giving an Account, 135.

${ }^{94}$ Ibid., 136.

${ }^{95}$ Lazzara, "Writing Complicity", 143.

${ }^{96}$ Brown, "In the Folds," 195-196.

${ }^{97}$ For example, the coverage of Aygan's confessions by the Kurdish left-wing paper Özgür Gündem. See Şahan and Balık. İtirafçı. Also see Argentinian journalist and activist Horacio Verbitsky's coverage of the retired navy captain Adolfo Scilingo's confessions about the death flights during the military rule between 1976 and 1983. See Payne, Unsettling Accounts.

${ }^{98}$ Argentina is a good example of how context shapes the reception of public confessions of perpetrators. Although earlier confessions by a police inspector and by a corporal did not raise a public storm, mainly because they were of low-rank and they made confessions in 1983 "amidst the grueling revelations of former disappeared" (Robben, Political Violence, 418n3), the confessions of Adolfo Scilingo, a retired navy captain led to a public debate, a new wave or prosecutions and an institutional apology, this in spite of the similarity between his performance and rhetoric and that of the two other confessors. This can be explained partly by how the first journalist who interviewed Scilingo framed his confessions. For a discussion of the consequences of Scilingo's confessions, see Payne, Unsettling Confessions; Lazzara, "Complicity and Responsibility"; Robben, Political Violence.
} 
criminalization of oppositional voices, and this context is clearly an obstacle to systemic change. To achieve this change, there is a need to rethink and subvert the norms underlying confessional discourse and reveal the workings of power in the confessional form. Our aim in this article has been to invite the reader to consider the intricacies of confessional speech-acts, their complex consequences, and their risks and limitations in establishing truths or delivering on justice for past state crimes. Unpacking the supposed opposition between remaining silent and the act of speaking out, we found that confession of a crime does not always reveal things, but in some subtle (or not so subtle) ways also conceal them.

\section{Compliance with ethical standards}

Conflict of interest The authors declare that they have no conflict of interest.

Open Access This article is licensed under a Creative Commons Attribution 4.0 International License, which permits use, sharing, adaptation, distribution and reproduction in any medium or format, as long as you give appropriate credit to the original author(s) and the source, provide a link to the Creative Commons licence, and indicate if changes were made. The images or other third party material in this article are included in the article's Creative Commons licence, unless indicated otherwise in a credit line to the material. If material is not included in the article's Creative Commons licence and your intended use is not permitted by statutory regulation or exceeds the permitted use, you will need to obtain permission directly from the copyright holder. To view a copy of this licence, visit http://creativecommons.org/licenses/by/4.0/.

\section{References}

Agamben, G. (1999). Remnants of Auschwitz: The witness and the archive. New York: Zone Books.

Akçura, B. (2010). Teşkilatın Adamları (the men of the organization). Istanbul: Postiga.

Altınay, A. G. (2004). The myth of the military-nation, militarism, gender, and education in Turkey. Basingstoke: Palgrave Macmillan.

Arendt, H. (2006). Eichmann in Jerusalem: A report on the banality of evil. Penguin Classics.

Arman, A. (2002). "Devlet bizi dağdan indirmeyecekti (the state should not have brought us back from the mountains)." Hurriyet, February 9. http://webarsiv.hurriyet.com.tr/2002/02/09/86860.asp. Accessed 10 Sept 2018

Austin, J. L. (1962). How to do things with words. Oxford: Clarendon Press.

Avc1, H. (2010). Haliç’te yaşayan Simonlar: Dün devlet, bugün cemaat (Simons who live in Haliç: Yesterday the state, today the community). Istanbul: Angora Yayınc1lik.

Baert, P. (2015). The existentialist moment; The rise of Sartre as a public intellectual. Cambridge: Polity Press.

Bozarslan, H. (1999). 'Network-building, ethnicity and violence in Turkey', Abu Dhabi ECSSR: 1-57.

Brooks, P. (2000). Troubling confessions: Speaking guilt in law and literature. Chicago: University of Chicago Press.

Brooks, P. (2005). The future of confession. Law, Culture and the Humanities, 1, 53-74. https://doi. org/10.1191/17438721051w005oa.

Brown, W. (1996). In the 'folds of our own discourse': The pleasures and freedoms of silence. University of Chicago Law School Roundtable, 3(1), 185-197.

Butler, J. (2005). Giving an account of oneself. New York: Fordham University Press. https://doi.org/10.5422 /fso/9780823225033.001.0001.

Çakır, R. (n.d.). Interview with Hanefi Avc1. NTV. 26.8.2010. https://www.youtube.com/watch?v=-I95LZ_ OR_g. Accessed 10 Sept 2018

Cavell, S. (n.d.). Philosophy the day after tomorrow. Cambridge: Harvard University Press. 
Chaniotis, A. (2009). Ritual performances of divine justice: The epigraphy of confession, atonement, and exaltation in Roman Asia minor. In H. M. Cotton, R. G. Hoyland, J. J. Price, \& D. J. Wasserstein (Eds.), From Hellenism to Islam: Cultural and linguistic change in the Roman Near East. Cambridge: Cambridge University Press.

Çiçek, N. (2009a). Itirafçı: Karanlık dönemin tetikçileri (The repentant: The hitmen of dark times). Istanbul: Timaș Yayınları.

Çiçek, N. (2009b). Gerçek cellat kim: Abdülkadir Aygan anlatıyor (Who is the real hangman: Abdülkadir Aygan tells). İstanbul: Neden Kitap.

Coetzee, J. M. (1985). Confession and double thoughts: Tolstoy, Rousseau, Dostoevsky. Comparative Literature, 37(3), 193-232. https://doi.org/10.2307/1771079.

Cohen, S. (1995). State crimes of previous regimes: Knowledge, accountability and the policing of the past. Law \& Social Inquiry, 20(1), 7-50. https://doi.org/10.1111/j.1747-4469.1995.tb00681.x.

Cohen, S. (2001). States of denial: Knowing about atrocities and suffering. Cambridge: Polity.

Docherty, T. (2012). Confessions: The philosophy of transparency. London: Bloomsbury Academic.

Doxtader, E. (2011). A question of Confession's discovery. Rhetoric Society Quarterly, 41(3), $267-281$. https://doi.org/10.1080/02773945.2011.575329.

Düzel, N. (n.d.). "JiTEM itirafçısı Abdülkadir Aygan anlatıyor (JiTEM's repentant Abdülkadir Aygan tells)." Taraf, 29 January 2009. http://m.bianet.org/bianet/siyaset/112200-aygan-olmedi-hastaneden-alip-yineinfaz-ettik. Accessed 10 Sept 2018

Ertür, B. (2016). The conspiracy archive: Turkey's deep state on trial. In S. M. Stewart \& H. van Rijswijk (Eds.), Law, Violence, Memory: Uncovering the Counter-Archive (pp. 177-194). Abingdon: Routledge.

Felman, S. (1992). Testimony: Crises of witnessing in literature, psychoanalysis, and history. London: Routledge.

Foster, D., Haupt, P., \& De Beer, M. (2005). The theatres of violence: Narratives of protagonists in the South African conflict. Cape Town: Institute of Justice and Reconciliation.

Foucault, M. (2010). The government of self and others, lectures at the Collège de France 1982-1983. Edited by Frederic Gros, translated by Graham Burchell, New York: Palgrave Macmillan.

Foucault, M. (2014a). On the government of the living: Lectures at the Collège de France, 1979-1980. Translated by Graham Burchell. Basingstoke: Palgrave Macmillan.

Foucault, M. (2014b). Wrong-doing, truth-telling: The function of avowal in justice. Translated by Stephen W. Sawyer. Chicago: University of Chicago Press.

Göçek, F. M. (2015). Denial of violence: Ottoman past, Turkish present, and collective violence against the Armenians, 1789-2009. New York: Oxford University Press.

Gürbilek, N. (2016). Sessizin Payl (the share of the silent). İstanbul: Metis Kitap.

Hamber, B., \& Wilson, R. A. (2003). Symbolic closure through memory, reparation and revenge in postconflict societies. In E. Cairns \& M. D. Roe (Eds.), The Role of Memory in Ethnic Conflict (pp. 144-168). London: Palgrave Macmillan. https://doi.org/10.1057/9781403919823_9.

Harré, R., \& van Langenhove, L. (1999). Positioning theory: Moral contexts of intentional action. Oxford: Blackwell. Hepworth, M., \& Turner, B. S. (1982). Confession: Studies in deviance and religion. London: Routledge Kegan Paul. Heyd, U. (1973). Studies in old ottoman criminal law. Oxford: Oxford University Press.

Huggins, M. K., Haritos-Fatouros, M., \& Zimbardo, P. G. (2002). Violence workers: Police torturers and murderers reconstruct brazilian atrocities. Berkeley: University of California Press.

Jelin, E. (2016). Investigating what happened: On truth commissions in processes of transition. International Sociology, 31(6), 764-773. https://doi.org/10.1177/0268580916667439.

Kafadar, C. (1989). Self and others: The diary of a dervish in seventeenth century Istanbul and first-person narratives in ottoman literature. Studia Islamica, 69, 121-150.

Kaufmann, D. (2016). A plea for perlocutions. Conversations: The Journal of Cavellian Studies, 4, 43-60.

Kilıç, E. (2009). Jitem ve Türkiye'nin faili meçhul tarihi (JiTEM and the history of extrajudicial killings). İstanbul: Timaş Yayınları.

Lazzara, M. (2016a). Writing complicity: The ideological adventures of Mariana Callejas. Radical History Review, 124, 141-152. https://doi.org/10.1215/01636545-3160024.

Lazzara, M. (2016b). Complicity and responsibility in the aftermath of the Pinochet regime: The case of $E l$ Mocito. Rubrica Contemporanea, 5(9), 59-76.

Lewis, B. (2004). From babel to dragomans: Interpreting the Middle East. New York: Oxford University Press.

Lorenzini, D. (2015). Performative, passionate, and Parrhesiastic utterance: On Cavell, Foucault, and truth as an ethical force. Critical Inquiry, 41(2), 254-268. 
Lovitt, C. (1992). The rhetoric of murderers' confessional narratives: The model of Pierre Riviere's memoir. Journal of Narrative Technique, 22(1), 23-34.

Moon, C. (2008). Narrating political reconciliation: South Africa's truth and reconciliation commission. Lanham: Lexington Books.

Navaro-Yashin, Y. (2002). Faces of the state: Secularism and public life in Turkey. Princeton: Princeton University Press.

Neier, A. (1999). Rethinking truth, justice, and guilt after Bosnia and Rwanda. In C. Hesse \& R. Post (Eds.), Human rights in political transitions: Gettysburg to Bosnia (pp. 39-52). New York: Zone Books.

Payne, L. (2008). Unsettling accounts: Neither truth nor reconciliation in confessions of state violence. Durham: Duke University Press.

Peters, R. (2005). Crime and punishment in Islamic law: Theory and practice from the sixteenth to the twentyfirst century. Cambridge: Cambridge University Press.

Radstone, S. (2006). "Cultures of confession/Cultures of testimony: Turning the subject inside out." In: Modern confessional writing: New critical essays, (ed) Jo Gill, pp. 166-179. London: Routledge.

Reynolds, D. F. (2001). Interpreting the self: Autobiography in the Arabic literary tradition. Berkeley: University of California Press.

Robben, A. C. G. M. (2005). Political violence and trauma in Argentina. Pennsylvania: University of Pennsylvania Press.

Rogers, J. (2011). Nostalgia for a reconciled future. Griffith Law Review, 20(2), 252-270. https://doi. org/10.1080/10383441.2011.10854698.

Sabuktay, A. (2010). Devletin yasal olmayan faaliyetleri: Susurluk olayı'na hukuk-siyaset kuramından bakış (The state's illegal activities: The Susurluk incident from the perspective of legal and political theory). Istanbul: Metis Kitap.

Șahan, T. and Balık, U. (2004). İtirafçı: Bir JiTEM'ci anlattı (the repentant: A JiTEM member speaks). Aram Yayınları.

Saymaz, İ. (2014). "Hanefi Avcı: 28 Șubat’ta bile insanlar bu kadar susturulmadı." Radikal, 01 July. http://www.radikal.com.tr/politika/hanefi-avci-28-subatta-bile-insanlar-bu-kadar-susturulmadi-1199567/. Accessed 10 Sept 2018

Scott, M. B., \& Lyman, S. M. (1968). Accounts. American Sociological Review, 33(1), 46-62.

Shaw, R. (2007). Memory frictions: Localizing the truth and reconciliation Commission in Sierra Leone. The International Journal of Transitional Justice, 1(2), 183-207. https://doi.org/10.1093/ijtj/ijm008.

Söyler, M. (2015). The Turkish deep state: State consolidation, Civil-Military Relations and Democracy. Oxon: Routledge.

Sykes, G. M., \& Matza, D. (1957). Techniques of neutralization: A theory of delinquency. American Sociological Review, 22(6), 664-670. https://doi.org/10.2307/2089195.

Taylor, C. (2010). The culture of confession from augustine to foucault: A genealogy of the 'Confessing Animal. New York: Routledge.

Tell, D. (2008). The 'shocking story' of Emmett Till and the politics of public confession. The Quarterly Journal of Speech, 94(2), 156-178. https://doi.org/10.1080/00335630801975426.

Terry, D. P. (2006). Once blind, now seeing: Problematics of confessional performance. Text and Performance Quarterly, 26(3), 209-228.

Uçarlar, N., \& DİSA. (2015). Hiçbir şey yerinde değil: Çatışma sonrast süreçte adalet ve geçmişle yüzleşme talepleri (Nothing is in its place: Demands for justice and accounting for the past in the post-conflict period). Ankara: İletişim Yayınları.

Yaraș, D. (2012). "Abdülkadir Aygan: Ha PKK, ha JiTEM (Abdülkadir Aygan: PKK, JiTEM all the same)." Haber Ajanda, October. http://cdn.haberajanda.com.tr/contents/files/dergiler/Ekim2012/index.html. Accessed 10 Sept 2018

Yıldı, Y. Y. (2019). "Confession as Disavowal: JiTEM officers confessing atrocities against Kurds during the 1990s", in: Kurds in Turkey: Ethnographies of heterogeneous experiences. eds. Adnan Çelik and Lucie Drechselova. Lanham, MD: Lexington Books.

Zerubavel, E. (2006). The elephant in the room: Silence and denial in everyday life. Oxford: Oxford University Press.

Publisher's note Springer Nature remains neutral with regard to jurisdictional claims in published maps and institutional affiliations. 
Dr Yeșim Yaprak Yıldız is currently a Lecturer in the Department of Sociology at Goldsmiths, University of London. She finished her PhD in Sociology at the University of Cambridge in 2018. Her research focuses on different forms of truth production and truth-telling in the aftermath of state-led atrocities. She is currently working on her monograph on production of truth and subjectivity in public confessions of Turkish state actors on state violence against Kurds during the 1990s. She has also worked on human rights violations in Turkey for many years on a wide range of issues from torture and ill-treatment to freedom of expression, women's rights and refugee rights.

Dr Patrick Baert is Professor of Social Theory at the University of Cambridge and a Fellow of Selwyn College, Cambridge. He is the co-author of The Dark Side of Podemos? Carl Schmitt and Contemporary Progressive Populism (2018), Conflict in the Academy; A Study in the Sociology of Intellectuals (2015), author of The Existentialist Moment; The Rise of Sartre as a Public Intellectual (2015) and co-editor of Ideas on the Move in the Social Sciences and Humanties; The International Circulation of Paradigms and Theorists (2020). His most recent publications on the sociology of intellecuals have appeared in the American Journal of Cultural Sociology, the Sociological Review and the European Journal of Social Theory. 